\title{
The Italian “alcohol question” from 1860 to 1930: Two opposing scientific interpretations
}

\author{
Enrico Petrilli and Franca Beccaria \\ Eclectica - Institute for Training and Research - Torino, Italy
}

\begin{abstract}
Background: In recent years, English-speaking and Northern European alcohol researchers have turned a historical gaze towards their subject, and in particular have explored how a medical view attempted to describe and explain phenomena such as alcohol abuse and addiction. Although there was a heated and prolific debate in Italy in the late 19th and early 20th centuries, there are few historical studies of the first scholars' thoughts on alcohol-related problems.
\end{abstract}

Aims: The article depicts how the Italian scientific community interpreted and explained alcohol-related concerns following the emergence of the alcohol issue in the late 19th century. Specifically, the stances of the two main groups of scientists who dealt with the issue, the Positive School of Criminology and Legal Socialism, are examined.

Method: The article is based on the materials collected by the Italian research group during a comparative study carried out as part of the ALICE RAP project. More than 40 books and five scientific journals were consulted.

Results: Medical-related concerns were never predominant in the late 19th-century Italian debate on the alcohol question, but were addressed in the broader discussion of criminality, where positivists' and legal socialists' perspectives both focused mainly on social consequences, albeit with differing interpretations of causalities and remedies.

Sociologists have directed their attention to the history of the concepts of alcohol abuse and addiction only in recent years. A turning point in this field was Levine's paper "The Discovery of Addiction" (1978), where he analyzes how the so-called disease model of alcohol addiction changed thinking on alcohol-related problems in the late 18th and early 19 th centuries ${ }^{1}$.

Scholars from temperance cultures, namely Nordic and English-speaking societies, were the first to show interest in the alcohol question (Levine, 1993). In the 18th century, alcohol misuse and drunkenness became an object of study with the establishment of alcohol-related questions on the medical agenda (Room, 2006; Ruuska, 2013). However, the first concerns were not about alcoholism, but were associated with the threat that alcohol abuse posed to the

${ }^{1}$ The introduction by Barrows and Room (1991) is recommended as further reading. moral and social order (Ferentzy, 2001; Nicholls, 2008), and physicians' explanations were not focused only on the patient's body, but also investigated the socio-cultural sphere (Ruuska, 2013).

But under the new bourgeois "gaze," the center of social control soon shifted to the individual (Foucault, 1965), a phenomenon described as the "individualization of social problems” (Conrad \& Schneider, 1995, p. 222). In the prevailing interpretation, alcoholism was "a progressive disease-the chief symptom of which is loss of control over drinking behavior, and whose only remedy is abstinence from all alcoholic beverages” (Levine, 1978, p. 293). During the 19th century, the medical approach was outlined ever more clearly in the writings of Trotter and Huss (Ruuska, 2013), and the treatment of alcohol-related problems was increasingly seen as falling within the purview of doctors and medical institutions (Barrows \& Room, 1991).

Correspondence: Enrico Petrilli, Eclectica, Via Silvio Pellico, 1, 10125 Torino, Italy. Telephone: +39 011 4361505; Fax: +39 011 0200022; E-mail: petrilli@eclectica.it

Financial support: The research leading to these results or outcomes has received funding from the European Union's Seventh Framework Programme for research, technological development and demonstration under grant agreement no. 266813-Addictions and Lifestyle in Contemporary Europe-Reframing Addictions Project (ALICE RAP). Participant organisations in ALICE RAP can be seen at http://www.alicerap.eu/about-alice-rap/partners.html

Declaration of interests: Enrico Petrilli has no conflicts of interest. Franca Beccaria is a member of the Scientific Laboratory of the Osservatorio Permanente sui Giovani e l'Alcool (Permanent Observatory on Youth and Alcohol) in Rome, an association which is mainly funded by the Italian Breweries Association. She receives no compensation for this work, though her expenses for one/two meeting/s per year are reimbursed. In 2012, she received an honorarium from ERAB (The European Foundation for Alcohol Research, an independent alcohol research foundation supported by The Brewers of Europe) for participating in a project entitled "Underage drinking: A report on drinking in the second decade of life in Europe and North America." ERAB also reimbursed her travelling costs for a meeting in Montreal and a meeting in Brussels. Together with the University of Torino (applicant) she received a grant from ERAB for a study entitled "Images of adolescent alcohol use and health in Italy: A study of teenagers' drinking and societal reactions to it” (2012-2013). The authors alone are responsible for the content and writing of this article.

Keywords: alcoholism, alcohol history, Legal Socialism, Positive School of Criminology, Italy 
This article will present how the Italian scientific community interpreted and explained the alcohol question following its emergence in Italy in the late 19th century, a century later than in Nordic and English-speaking societies. We intend to extend Cottino's analysis (1985a) on Positive School theory to include the Legal Socialism perspective, as these were the two main groups of scientists who studied the alcohol question in this historical period.

Unlike much of the international literature, our paper does not focus solely on how physicians faced alcohol-related problems in the late 19th century, but on how the broader scientific community understood the issue. We thus include the points of view of criminal anthropologists, sociologists and jurists, for two main reasons. First, a previous article on the conceptualization of alcohol and drug addictions among Italian scholars in those years found that the different scientific disciplines had an important role (Beccaria \& Petrilli, submitted). Second, the hypothesis driving this article is that the Italian debate was not dominated by a medical perspective, that is, one focusing on the consequences for individual health. Indeed, while the Positive School stressed the legal issue because of its concern with public order, Legal Socialism showed a social interest in improving the living conditions of the underprivileged. The debate between these two opposing scientific views thus developed within the context of a broader discussion on criminality

\section{Methods}

The article is based on the material collected in a comparative historical study conducted as part of the ALICE RAP project, covering more than 40 books and five scientific journals (112 issues) published from 1860 to 1930 (Table 1).

\section{Table 1}

The scientific journals

\begin{tabular}{lcc}
\hline Journal & Issues & $\begin{array}{c}\text { Years of } \\
\text { publications }\end{array}$ \\
\hline $\begin{array}{l}\text { Archives of Criminal } \\
\text { Anthropology, Psychiatry, Forensic }\end{array}$ & 50 & $1880-1930$ \\
$\begin{array}{l}\text { Science and related Science } \\
\text { Experimental Journal of Psychiatry } \\
\text { and Forensic Science of the Mental } \\
\text { Alienation }\end{array}$ & 31 & $1896-1930$ \\
Journal of Forensic Science & 11 & $1894-1904$ \\
Journal of Forensic Science and & 10 & $1897-1920$ \\
$\begin{array}{l}\text { Medical Jurisprudence } \\
\text { Zacchia-Archives of Forensic, } \\
\text { Social and Criminological } \\
\text { Medicine }\end{array}$ & 10 & $1921-1930$ \\
\hline
\end{tabular}

The journals that were selected were those that were most complete in terms of issues and those that covered the widest period. None were digitized, so every volume index — and the subject index, when available-was searched manually to find material dealing with alcohol topics. In selecting books, on the other hand, we started collecting those dedicated solely to the alcohol question, such as Colajanni (1887) and Zerboglio (1892). At the same time, we culled the writings of the most important scholars of the time who investigated the alcohol question alongside other issues, such as Ferri (1895) and Lombroso (1897). Lastly, we searched the bibliographies of the journals and books we had selected to find other significant texts that were not entirely devoted to the alcohol issue but dealt with it, including Puccinotti (1856) and Morselli (1900).

In analyzing the collected material, we first performed a content analysis of the scientific journals to determine when alcohol-related terms entered the academic debate and how often they were used. In the second phase of the investigation, books and journals were qualitatively analyzed to identify the meanings of these terms.

\section{Results}

\section{The Industrial Revolution's Influence on Italian Drinking}

In reviewing the historical studies dealing with the genesis of industrialization in Italy, Bonelli (1999) emphasized that there are various outlooks on this matter. Romeo (1959) saw 1880 as a crucial turning point on the path towards the industrial economy, while Cafagna (1989) described Italian industrial development as a pattern of fits and starts, in several waves. Lastly, Romano (1991) considered what happened in the late 19th century as preparation for the country's "real” industrialization in the 1960s.

As we have seen, it is difficult to determine exactly when the industrial revolution began in Italy, though in any case, it was later than other European nations (Hobsbawm, 1962). We can say, however, that there was a slow process of change in the Italian economy from the late 18th century to the first 80 years of the 19th century. This was the socalled "agrarian-mercantile accumulation" phase (Bonelli, 1999), a period in which Italy began to export food and raw materials, the first factories were established, and the agriculture-manufacturing sector developed.

Italy's unification in 1861 was one of the main forces in modernizing the economy and society. The new government managed to increase the economic impact of agricultural exports through a liberal policy and by extending public transport, and was able to channel agricultural capital to other areas of the economy, accelerating the processes of industrialization (Forgacs, 1990).

If we shift our attention from the structural dimension to population conditions, the changes produced by industrialization become dramatic. Besides encouraging migration to North and South America, the European crisis of the 1880s also resulted in migration within the country towards the densely populated cities of the North (Morgan, 
1988). As the overpopulation of these areas unbalanced the labour market, employers could count on large pools of underpaid workers, whose living standards were thus miserable (Vecchi, 2011). At the same time, the national debt grew, and new taxation to balance it increased the discontent among the population (Lepre \& Petraccone, 2008).

As had occurred earlier in the rest of Western world, where a concern about alcohol abuse became one of the characteristics that set industrialized societies apart from pre-industrialized ones (Levine 1984; Vaillant, 2009), the process of industrialization also partially changed the traditional relationship between Italians and alcohol, which involved nourishment, ritual, and convivial values, by increasing the availability and consumption of alcoholic beverages (Figurelli, 1978; Morgan, 1988). The changes were not limited to the amount of alcohol drunk; new drinking patterns also emerged. Urbanization caused an exponential growth in the number of bettole, or taverns, throughout Italy, to the extent that a question about them was raised in Parliament by Zerboglio (Cronaca Sociale, 1910). The bettole were portrayed either as "headquarters of crime" (Carrara, 1908, p. 165) where desperation and social exclusion reigned, or as the only place where the oppressed working-class population could meet and amuse themselves (Cottino, 1985b).

Both Figurelli (1978) and Garfinkel (2006) point out that alcohol-related problems, like other deviant behaviors, were in the background in Italian pre-unification and preindustrial society, but as society modernized they became one of the "social evils" that were widely debated by both scholars (Cottino, 1991) and politicians (Morgan, 1988). Our content analysis of scientific journals shows that this issue gained increasing attention in the academic world starting from the mid-19th century: coverage of alcoholrelated issues increased from seven articles in the years $1860-1889$ to 45 in 1890-1909, and to 71 in 1910-1930.

In Italy as elsewhere, the alcohol question did not have a strictly medical connotation when it first arose, as the main concerns were the consequences in terms of public order and morality. For this reason, the first field to deal with it was medical jurisprudence, as represented by Puccinotti (1856) and Zeliotto (1866), and the main topic addressed was drunkenness.

Though these two authors were the first to study alcoholrelated problems in modern Italy, the debate quickly expanded beyond their initial perspective. As noted by Cottino (1991), these were the years that saw a shift from Beccaria's Classical School formulation to one where extrajuridical factors were also taken into account when interpreting criminal activities. Whereas in Beccaria's theory (1794), criminal action depended both on a rational subject's cost/benefit calculation and on an inadequate system of sanctions, the new paradigms formulated at the end of the 19th century no longer reduced the crime problem to its penalty alone. The following section will explore these two new paradigms: the biological determinism of Lombroso's Positive School of
Criminology and Legal Socialism's social determinism (Cottino, 1985b).

\section{The Positive School of Criminology}

Cesare Lombroso is known as the founding father of modern criminology. But he was also the scholar who, more than any other, left his mark on Italian scientific debate of the 19th century, and one of the few intellectuals of the period who was able to influence a foreign audience (Marchetti, 2012; Papa, 1985). Lombroso's theories gained widespread consensus (and many critics) on the Italian cultural scene and gathered a large group of young lawyers (including Ferri and Garofalo) around him, giving rise to the so-called Positive School of Criminology.

The revolution that Lombroso brought about in criminal science in the 1870s was to shift the focus of the study of delinquency from its legal characteristics, which had been the main interest of the Classical School of Criminology, to the individual offender. For Lombroso, criminal behavior does not depend on a rational choice, but on bodily attributes of the born criminal (Marchetti, 2009). The idea of "atavistic and degenerate heredity of the born criminal and the criminaloid" (Ellwood, 1912) is the main concept in Lombroso's theory. In his view, the heredity of the perverted features is the main cause of criminality, because the offender has a "physical stigmata" (Muncie, 2005, p. 25), an inherited morbid condition which induces him to break the law.

There are two main alcohol-related themes in the Positive School writings that deserve attention. The first concerns legal issues and the second is close to the medical field: the effect of alcohol on crimes and the physical consequences of alcohol abuse. Remedies against alcohol abuse and alcoholism will also be discussed.

\section{The effect of alcohol on crimes}

These scholars saw alcohol as one of the chief factors accounting for criminal action, since it has the power to turn an honest man into an idle, lazy and violent person who is capable of breaking the law even when he is not under the influence. Alcohol use and abuse fosters law breaking in different ways.

At the first level, alcohol's disinhibiting power is directly linked to felonies: drinkers act unconsciously under its effect, or offenders drink to build up the courage to commit a crime (Lombroso, 1897). This occurs because alcohol intoxication "can create a real psychopathy” (Ferri, 1895, p. 702).

However, alcohol's indirect role in promoting crime was regarded as more significant and worrisome. Inns, taverns, and cabarets, the preferred meeting places for workers and deadbeats, were seen as hotbeds of vice where violent actions were carried out and crimes planned. Ferri (1897) scrutinized the relationship between hostelries and crime, comparing what happened in taverns and acquavitai (where alcohol was produced). The former were breeding grounds of crime, not simply because the substance was ingested there, but because drinkers remained there for a lengthy 
period. In fact, there was much less violence in the acquavitai, because purchasers stayed only long enough to buy and consume the product.

The second point these authors raise concerning the relationship between alcohol and delinquency gets close to the medical issue. Over time, in their view, alcohol consumption makes those who drink into habitual drinkers-alcoholics - and leads them to commit crimes in order to buy drink. This proves "the axiom that crime is a result of a special morbid condition inside our body" (Lombroso, 1897, p. 106-107). This situation is connected to "one of the most obvious and fatal effects of alcohol" (Ibid.): "pauperism” (poverty). Moreover, Lanza (1921) emphasized the economic burden of alcoholism: workers "waste" most of their daily earnings to get drunk, neglecting their family's needs.

Recognizing these multiple relations between alcoholic beverages and criminal action, the positivist scholars wondered which felonies drinkers commit most frequently. According to Ferri (1895), people are more likely to commit injuries and murders while intoxicated, and the chronic alcoholic is more prone to indecent behavior and crimes against property and people.

\section{The physical consequences}

What we have said so far illustrates how the Positivists' main concern was not drinkers' health, but public order. In those years, however, the scientific community began to view alcohol-related problems not only as moral and criminal issues, but also as a medical matter. Illuminating in this regard was the alarm raised by Zerboglio: "If alcoholism as the tendency to abuse alcoholic beverages is decreasing, alcoholism as disease is growing” (Zerboglio, 1892, p. 194).

The first medical issue addressed by these scholars was chronic alcoholism. This was not a temporary state like acute alcoholism (intoxication), but was defined as the consequence of prolonged alcohol abuse over time (Zerboglio, 1892), which "leads to an organic and psychic degeneration" (Ferri, 1892, p. 211). Some authors also mentioned alcoholics' inability to control their drinking: Lombroso (1880), for example, tells of a woman who mixed feces and wine in an unsuccessful attempt to abstain.

Nevertheless, the main concern of Lombroso and colleagues in the medical field was that "drinkers produce delinquent children” (Lombroso, 1897, p. 107). Pauperism was not regarded as the result of economic conditions; rather, it was believed that listlessness and inconstancy may have stemmed from morbid heredity, and idlers thus had degenerative traits, as did criminals. To demonstrate the enormous degenerative effect of alcohol on drinkers' children, Lombroso (1897) referred to statistical data, mentioning that 20 per cent of the criminals he examined had alcoholic parents, and citing exemplifying cases:

"In a period of 75 years, the descendants of a single progenitor, the drunken Max Jucke, included 200 robbers and murderers, 280 poor people suffering from blindness, idiocy, and phthisis, 90 prostitutes and 300 children who died early" (Lombroso, 1880, p. 307)

Lastly, positivist scholars pointed out that alcohol also reduced the inhibitory factors acquired through education, so that drinkers no longer restrained themselves from committing crimes or acting immorally. The physical degeneration thus accompanied a moral one.

To summarize the perspective of Lombroso and colleagues, alcohol abuse had a double impact on the drinker: both on his behavior (crime) and on his body (alcoholism). At the same time, the addicting powers of alcoholic beverages"body-pathogenic factors"-were important: in the same way that the criminal had a physical "stigmata," the alcoholic drank because of a biological predisposition.

\section{Remedies}

At a general level, Lombroso and Ferri had the same idea: offenders must be eradicated from society through decisive criminal penalties, otherwise they will pass on their pathogenic traits (Sbriccoli, 1975). But at the same time, pessimism reigned, as "no repressive law can fully succeed when it goes against our instincts, among which psychic excitement stands out” (Lombroso, 1897, p. 235).

Lombroso and colleagues proposed two types of solutions for the alcohol issue: administrative and penal. The former would include increasing alcohol taxes, taking action against counterfeit alcohol, and controlling tavern licenses. In addition, since public festivities such as those for saints' days promote delinquency, they should be limited (Lombroso, 1897). Penal remedies, on the other hand, would affect drinkers directly: through fines for drunkenness and detention in mental hospitals for alcoholics. Garofalo (1913) compared alcoholics to lunatics and epileptics, since all such people must be interned in mental hospitals so that they do not harm others.

\section{Legal Socialism}

In the same years, a second and opposing school of thought was Legal Socialism, espoused by those authors who agreed with the Positivists' experimental method but did not share the same belief in biological determinism, because they adhered to judicial culture's rediscovery of the social dimension (Stronati, 2012). According to Turati (1913), leader of this approach, crimes committed by the subordinate class do not depend on biological factors, as Lombroso believed, but are due to political and economic conditions (Sbriccoli, 1975).

Legal socialists regarded the relationship between crime and alcoholism identified by Lombroso and colleagues as spurious (Cottino, 1991), holding that the two coexist because they have a common origin: pauperism.

Colajanni, the first to analyze alcohol-related issues from a Legal Socialism perspective, defined alcoholism as a "pathological condition due to the misery generated by the present social organization” (1887, p. 165). Alcoholism is a "social disease" (Pistolese, 1907, p. 2), not a product of biological factors, because alcohol-related problems such 
as prostitution are determined by the disintegration of the social fabric resulting from industrialization and capitalism (Sbriccoli, 1975).

Industrialization forced workers into grinding labour and overwhelming jobs, so they "turn to alcohol thinking that it strengthens" (Pistolese, 1907, p. 146). Hence, hard work and poor nutrition drove workers to drink alcoholic beverages in the belief that they would provide nourishment. Allevi (1906) added that proletarians drank as a result of their alienating jobs, because alcohol "takes them away from the monotony of their lives” (p. 125). Alcoholic beverages and taverns had the important role of promoting sociability, providing an effective remedy against hypochondriasis and misanthropy, and combatting selfishness and presumption (Colajanni, 1887). Laureati (1905) added that "the main reason that pushes workers to patronize inns [. . .] is the lack of comfortable space at home where they can receive friends and acquaintances" (p. 378).

Concerning the heredity issue, Colajanni (1887) rejected Lombroso's idea of a pathological state inherited by alcoholics' children. Although he acknowledged that alcoholics' offspring have more mental and criminal problems, he saw family upbringing and social environment as the most influential factors in this process of degeneration. Not surprisingly, his major concern was not physical degeneration but intellectual degradation, which he depicted as "apathy, indifference and lack of concern about the individual's own state” (p. 126).

The legal socialists also disagreed with the Positive School regarding the solution to alcohol-related problems. They judged positivists' repressive methods to be ineffective, since they do "not uproot the seeds of the crime" (Pistolese, 1907 , p. 150). The measures they proposed would act on the socio-economic setting rather that at the individual level, because they maintained that change to the social environment was needed. At the macro level, they felt that it was necessary to create a more egalitarian economy by increasing workers' wages, abolishing child labour, and ensuring a less oppressive system of work. The population's living conditions must then be improved by providing better housing, increasing the average level of schooling and encouraging intellectual recreation through arts (Morselli, 1900; Pistolese, 1907).

\section{Conclusion}

The Positivist and Legal Socialist perspectives were the first scientific interpretations of alcohol-related problems in Italy that were able to address both the legal and socioeconomic dimensions and the health consequences. Medical-related concerns were never predominant in Italy, as they were in temperance cultures during the 19th century. The idea of alcoholism as a progressive disease was not a radical break in the approach to alcohol-related problems, but was embedded in wider legal and social thinking. The Positivist and Legal Socialist schools did not adopt a medical approach which explored the relationship between alcohol and health with an eye to patient care, but they developed this debate as part of their broader focus on criminality, in which their interpretations of causality and solutions differed. For the Positivists, alcohol abuse led to poverty and degenerate progeny, while for legal socialists it was poverty that caused alcoholism.

In view of both the traditional Italian drinking culture and these first scientific thoughts, the time has come to write a history of the Italian alcohol issue that is not confined to a medical focus, but sheds light on the particular nature of Italians' relationship with alcoholic beverages from preindustrial times to the present. A reflection of this kind would clarify why awareness of alcohol issues increased in post-unification Italy. Was this caused simply by a rise in alcohol consumption, or was it the result of a political conflict between bourgeois intellectuals and the clergy in the new Liberal state, as hypothesized by Garfinkel (2006)? A second interesting aspect to investigate would be the effect of these two schools of thought on political debate and alcohol policies, as several of the scholars we have mentioned- including Ferri and Colajanni-were also members of Parliament. Lastly, this study is a starting point for further research on how these scholars' interpretations of the alcohol question influenced Italy's scientific discourse on alcohol in the second part of the $20^{\text {th }}$ century.

\section{Acknowledgements}

The authors would like to thank Professor Paolo Tappero and Elena Gay, whose support was essential in improving our research, as they facilitated access to the Forensic Science Library in Torino.

\section{References}

Allevi, G. (1906). L'alcoolismo [Alcoholism]. Torino, Italy: Fratelli Bocca.

Barrows, S., \& Room, R. (1991). Drinking: Behaviour and belief in modern history. Berkeley, CA, United States: University of California Press.

Beccaria, C. (1794). Dei delitti e delle pene [On crimes and punishments]. Firenze: In Monaco.

Beccaria, F., \& Petrilli, E. (2014). The complexity of addiction: Different conceptualizations of alcohol and drug addiction(s) among Italian scholars in the late 19th and early 20th century. Social History of Alcohol and Drugs, 28, 34-56.

Bonelli, F. (1999). Economia, politica e società nella industrializzazione italiana [Economy, politics and society in the Italian industrialization]. In A. RossiDoria (Ed.), La fine dei contadini $e$ l'industrializzazione in Italia [The end of the peasants and industrialization in Italy] (pp. 7-39). Catanzaro, Italy: Rubbettino Editore.

Cafagna, L. (1989). Dualismo e sviluppo nella storia d'Italia [Dualism and development in the history of Italy]. Padova, Italy: Marsilio Editori.

Carrara, F. (1908). Antropologia criminale [Criminal Anthropology]. Milano, Italy: Vallardi. 
Colajanni, N. (1887). L'alcoolismo, sue conseguenze morali, sue cause [Alcoholism, its moral consequences, its causes]. Catania, Italy: Filippo Tropea Editore.

Conrad, P., \& Schneider, J. (1995). Medicine as an institution of social control: consequences for society. In N. J. Herman (Ed.), Deviance: A symbolic interactionist approach (pp. 212-231). New York, NY, United States: General Hall.

Cottino, A. (1985a). Science and class structure: Notes on the formation of the alcohol question in Italy (1860 1920). Contemporary Crises, 9, 45-53.

Cottino, A. (1985b). La questione sociale dell'alcool da Lombroso a Ferri [The social question of alcohol from Lombroso to Ferri]. In Gruppo di ricerca sui problemi dell'alcolismo e delle tossicodipendenze (Eds.), L'alcol nella società-Scienza, cultura e controllo sociale [Alcohol in society-Science, culture and social control] (pp. 11-32). Torino, Italy: Celid.

Cottino, A. (1991). L'ingannevole sponda [The deceptive bank]. Roma, Italy: Carrocci Editore.

Cronaca Sociale (1910). Cronaca Sociale. Rivista Internazionale di Scienze Sociali e Discipline Ausiliarie [Social Chronicle. International Journal of Social Sciences and Auxiliary Disciplines], 53(211), 470-480.

Ellwood, C. A. (1912). Lombroso's theory of crime. Journal of Criminal Law and Criminology, 2(5), 716723.

Ferentzy, P. (2001). From sin to disease: Differences and similarities between past and current conceptions of chronic drunkenness. Contemporary Drug Problems, 28, 363-390.

Ferri, E. (1892). Sociologia criminale [Criminal sociology]. Torino, Italy: Fratelli Bocca.

Ferri, E. (1895). L'omicidio [The murder]. Torino, Italy: Fratelli Bocca.

Ferri, E. (1897). L’alcolismo [Alcoholism]. La scuola positiva, 7.

Figurelli, M. (1978). L’alcol e la classe. Cenni per una storia dell'alcolismo in Italia [Alcohol and class. Outline for a history of alcoholism in Italy]. $L a$ Classe, 10(15), 93-136.

Forgacs, D. (1990). Italian culture in the industrial era, 1880-1980: Cultural industries, politics, and the public. Manchester, England: Manchester University Press.

Foucault, M. (1965). Madness and civilization. New York, NY, United States: Pantheon.

Garfinkel, P. A. (2006). In Vino Veritas: The construction of alcoholic disease in liberal Italy, 1880-1914. In M. Holt (Ed.), Alcohol: A social and cultural history (pp. 61-76). Oxford, England: Berg Publishers.

Garofalo, R. (1913). La criminalità in Italia nel 1911 secondo le relazioni dei Procuratori Generali [Italian Crime in 1911, according to the reports of Attorneys General]. Milano, Italy: Società Editrice Libraria.

Hobsbawm, E. (1962). Age of revolution 1789-1848. London, England: Weidenfeld \& Nicolson.

Lanza, C. (1921). Criminali ed abnormi alcolisti in rapporto alla loro pericolosità sociale [Criminals and aberrant alcoholics in relation to their social dangerousness]. La scuola Positiva, 1, 10-12.

Laureati, S. (1905). Zucchero e alcol nei loro rapporti agricoli, fisiologici e sociali [Sugar and alcohol in their agricultural, physiological and social relations]. Milano, Italy: Hoepli.

Lepre, A., \& Petraccone, C. (2008). Storia d'Italia dall'unità a oggi [History of Italy from the unification to today]. Bologna, Italy: Il Mulino.

Levine, H. G. (1978). The discovery of addiction: Changing conceptions of habitual drunkenness in America. Journal of Studies on Alcohol, 15, 493-506.

Levine, H. G. (1984). The alcohol problem in America: From temperance to alcoholism. British Journal of Addiction, 79(1), 109-119.

Levine, H. G. (1993). Temperance cultures: Alcohol as a problem in Nordic and English-speaking cultures”. In M. Lader, G. Edwards, \& D. C. Drummon (Eds.), The nature of alcohol and drug-related problems (pp.1636). New York, NY, United States: Oxford University Press.

Lombroso, C. (1880). Il vino nel delitto [The wine in crime]. In A. Graf, A. Cossa, C. Corradino, M. Lessona, S. C. de Martiis, G. Arcangeli, A. Mosso, G. Giacosa, G. Bizzozero, C. Lombroso, \& E. de Amicis (Eds.), Il vino: Undici conferenze [The wine: Eleven conferences]. Torino, Italy: Loescher.

Lombroso, C. (1897). L'uomo delinquente [The criminal man]. Milano, Italy: Hoepli.

Marchetti, P. (2009). Le 'sentinelle del male'. L'invenzione ottocentesca del criminale nemico della società tra naturalismo giuridico e normativismo psichiatrico [The nineteenth-century invention of the criminal enemy of society between legal naturalism and psychiatric normativism]. Quaderni fiorentini per la storia del pensiero giuridico moderno, 38, 1009-1080.

Marchetti, P. (2012). Lombroso, Cesare. Il contributo italiano alla storia del pensiero-Diritto [Lombroso, Cesare The Italian contribution to the history of Thought - Right]. Ottava appendice, 366-370.

Morgan, P. (1988). Industrialization, urbanization and the attack on Italian drinking culture. Contemporary Drug Problems, 15, 607-626.

Morselli, E. (1900). Trattato di terapia delle malattie mentali [Essay on mental illnesses treatment]. Torino, Italy: Unione Tipografico Editrice.

Muncie, J. (2005). Biological Criminology. In E. McLaughlin, \& J. Muncie (Eds.), The SAGE dictionary of criminology (pp. 25-27). London, England: Sage.

Nicholls, J. (2008). Vinum Britannicum: The “drink question” in early modern England. Social History of Alcohol and Drugs, 22(2), 190-208.

Papa, E. R. (1985). Criminologia e scienze sociali nel dibattito europeo sulla "scuola italiana" di antropologia criminale (1876-1900) [Criminology and social sciences in the European debate on the "Italian school" of criminal anthropology (1876-1900)]. In E. R. Papa (Ed.), Il positivismo nella cultura italiana [Positivism in the culture] (pp. 15-46). Milano, Italy: Franco Angeli. 
Pistolese, A. (1907). Alcolismo e delinquenza [Alcoholism and delinquency]. Torino, Italy: UTET.

Puccinotti, F. (1856). Lezioni di medicina legale [Lectures of legal medicine]. Milano, Italy: Borroni e Scotti.

Romano, R. (1991). Storia dell'economia italiana. L'età moderna: Verso la crisi (vol. 2) [History of the Italian economy. The modern age: Towards the crisis (vol. 2)]. Torino, Italy: Einaudi.

Romeo, R. (1959). Risorgimento e capitalismo [Italian unification and capitalism]. Bari, Italy: Laterza.

Room, R. (2006). Addiction concepts and international control. The Social History of Alcohol and Drugs, 20, 276-289.

Ruuska, A. (2013). Consequences and behaviour problematised: The establishment of alcohol misuse as an object of empirical inquiry in late 18th- and early 19th-century European medicine. Nordic Studies on Alcohol and Drugs, 30(1-2), 13-32.

Sbriccoli, M. (1975). Il diritto penale sociale (1883-1912) [Social penal law (1883-1912)]. Quaderni fiorentini per la storia del pensiero giuridico moderno, 3-4, 556-642.

Sournia, J. C. (1990). A history of alcoholism. Oxford, England: Basil Blackwell.

Stronati, M. (2012). Il socialismo giuridico e il solidarismo [Legal socialism and solidarism]. Il contributo italiano alla storia del pensiero-Diritto. Ottava appendice (pp. 405-412).

Turati, F. (1913). Il delitto e la questione sociale: appunti sulla questione penale [Crime and the social question: Notes on the penal issue]. Bologna, Italy: La controcorrente.

Vecchi, G. (2011). In ricchezza e in povertà. Il benessere degli italiani dall'Unità a oggi [For richer or poorer. The wellbeing of Italian from the unification to the present]. Bologna, Italy: Il Mulino.

Vaillant, G. E. (2009). The natural history of alcoholism revisited. Cambridge, MA, United States: Harvard University Press.

Zeliotto, P. (1866). L'ubriachezza: Discorso tenuto agli uditori di medicina legale nello ospedale civile generale di Venezia [Drunkenness: Speech given to the legal medicine audience of the Venice civil hospital]. Venezia, Italy: Tipi Locatelli.

Zerboglio, A. (1892). L'alcoolismo. Studio sociologicogiuridico [Alcoholism. Legal-sociological study]. Torino, Italy: Fratelli Bocca. 